\title{
NOTES
}

\section{“BOZ'S OPINIONS OF US": WHITMAN, DICKENS, AND THE FORGED LETTER}

On August 11, 1842, Walt Whitman published "Boz's Opinions of Us" in the Evening Tattler. The article reprinted a letter that Charles Dickens had apparently written to The Morning Chronicle following his first trip to the United States. The letter describes a variety of "dark spots of American character."1 Whitman's Tattler article claimed this letter was the full text from which three paragraphs had been excerpted and printed in the same paper more than a week earlier. ${ }^{2}$ Both the excerpts and the full letter inspired a great deal of comment from other editors and writers. Most expressed their shock and outrage at the tenor of Dickens' opinions and the stark contrast between the sentiments in the letter and those the author had expressed in public and private gatherings during his trip to America. Newspapers had already been reprinting a circular that Dickens had written early in July regarding international copyright that fiercely criticized those with a "strong interest in the existing system of piracy and plunder." 3 Now came this new insult; Whitman writes, "Lest there be some misunderstanding, we will add that there are two letters in the Chronicle from Mr. Dickens. The first one (which we do not publish because it has already appeared extensively in the papers) was written some time before the one that follows" (1:148). This second letter, apparently written little more than a week later, points out, among other things, that "[t]he great fault of the American people is their worship of pelf" (1:149).

As Whitman's accompanying article makes clear, he shared the sense of betrayal expressed by his colleagues, noting, "How sadly have we been disappointed!" (1:148). Despite his disappointment, however, he resisted joining in the harsh criticism. Indeed, much of his article is devoted to praising passages of the Dickens letter. This may be the reason that Herbert Bergman, in commenting upon the piece in his collection of Whitman's journalism, states only that it "reflects WW's continued interest in Dickens. WW had written about Dickens in 'Boz and Democracy,' Brother fonathan, I (February 26, 1842), 243-44; and in 'Dickens and Democracy,' NYA [New York Aurora], April 2, 1842" (1:505). It is understandable that Bergman ties this piece to these other, more favorable, editorials. Rather than an attack on Dickens, the article appears to be an attempt to justify Dickens' remarks, and it speaks approvingly of several passages in the letter: "Another thing we cotton to in the letter. It is where he cuts the flimsiness of our American aristocracy. Reader, look over that part of the epistle twice" (1:148). In addressing this passage, Bergman notes, "WW's characteristic democratic sentiments are evident here" (1:505).

While this is certainly true, the vehicle Whitman used to express his views in this case takes on greater interest and importance when we recognize what 
Bergman fails to mention: the Dickens letter that Whitman published in the Evening Tattler was in fact a forgery. It was quickly reprinted and excerpted in various forms by other newspapers, and, although it was soon recognized as a fake and denounced by many, it further alienated Dickens from his American audience. Dickens wrote to a friend at the time, "In America they have forged a letter with my signature [. . .]. It has been widely distributed all over the States; and the felon who invented it is a 'smart man' of course. You are to understand that it is not done as a joke, and is scurrilously reviewed." ${ }^{4}$ One scholar has noted of the episode, "In this welter of controversy, the real Charles Dickens was forgotten; a new man had been created by the forger and by those who accepted the forgeries as deserving of serious response." ${ }^{5}$ As the first journalist to print the forged passages, Whitman - perhaps unwittinglycontributed to the creation of a "new man" quite different from the popular figure Dickens had been prior to his trip to the United States.

Dickens scholars, long recognizing the role Whitman played in the first appearance of the letter, have been decidedly cautious in assigning blame to him for the forgery. The editors of the Pilgrim Edition of The Letters of Charles Dickens, who provide the most thorough recounting of the episode, state, "Walt Whitman [. . . must have sanctioned the three forged paragraphs which had appeared in the Tattler on August 2 or 3 (though possibly not knowing they were forgeries), also this article of 11 Aug and the ten weak paragraphs which were now added in the pretext of at last giving the forged letter complete [. . .]. Earlier, Whitman had shown himself to be one of CD's warm admirers." Sidney Moss, on the other hand, writes that "the forgery originated in the New York Evening Tattler, which Walt Whitman was editing at the time," and refers to the author of the accompanying article as "the forger." In a note, Moss hedges a bit more, remarking that the article is "presumed to be Whitman's." 8

In the absence of any clear evidence, there is no way to be certain if Whitman forged the letter, knowingly published the forgery, or simply published what was given to him. Nevertheless, it is difficult to imagine that he was completely unaware of the letter's origin. After the publication of the initial three passages, several papers had noted the discrepancies between those excerpts and Dickens' actual circular; therefore, Whitman's attempt in his article to prevent "misunderstanding" by asserting that there were "two letters in the Chronicle from Mr. Dickens" seems a belated and implausibly convenient defense (1:148). According to another paper's quotation of the August 10 Evening Tattler, Whitman had promised to publish the complete letter from which the three paragraphs had been taken and wrote, "We don't believe another office in the city has the London paper containing it." ${ }^{\text {" Checking the }}$ newspaper would have been relatively easy, and one is left with the unpleasant choice of determining whether Whitman was attempting to create a flimsy cover for the forger or if he had simply failed to confirm the reliability of the material he published. ${ }^{10}$

Whitman scholars have not addressed this question, and those who have commented upon the article at all have said little more than Bergman. Gay Wilson Allen refers to it briefly in his biography, stating, "we find Whitman, as in the Aurora, once more defending Dickens. Americans, he says, are too ready 'to pet and caress a foreign lion' and deserve such a lesson as Dickens is 
giving them; he came over to effect an international copyright law, which he did not get and is understandably disgruntled; and he correctly exposes 'the flimsiness of our American aristocracy." "'11 Allen, like Bergman, emphasizes those parts of the article that are in accordance with the common perception of the poet as a supporter of Dickens, and he overlooks the more troubling aspects of the piece and its results. While not addressing "Boz's Opinions of Us" directly, Jerome Loving comes much closer to the mark in his recent biography of Whitman:

Although Whitman never met Dickens, he was one of the many journalists who flocked to cover Boz's first and famous visit to New York City in February 1842. Within months of his return to England, Dickens was falsely accused of printing a letter with sentiments "so derogatory to our country," in the words of Philip Hone, the city's one-time mayor and influential friend of Whig politicians, "that nothing is left for Mr. Dickens but to deny its authenticity."12

Again, the central role Whitman played in this dispute suggests that, as editor of the Evening Tattler, he did more than merely report on the visit: "Boz's Opinions of Us" tapped into popular sentiment, intensified the backlash against Dickens and, perhaps not incidentally, gained the Evening Tattler greater publicity.

The article raises questions regarding what is generally viewed as Whitman's unfailing support for Dickens during these years, as the forgery stoked the fires of public opinion raging against the British author. At the same time, as Allen points out, the letter served as a vehicle for Whitman to criticize his fellow Americans, even while under the guise of defending them. The article contains his first expression of support for an international copyright law, for example, a cause he would champion throughout his career. If Whitman was in fact responsible for writing the forgery as well as publishing it, then it would explain his support for the letter's sentiments and stand as an intriguing new example of his journalism. Regardless of the poet's agency in writing or sanctioning the forgery, his involvement in first presenting it to the public complicates our understanding of his feelings about Dickens and provides a hitherto unrecognized example of his editorial maneuvering.

Grinnell College

MARTIN T. BUINICKI

\section{NOTES}

1 Walt Whitman, The fournalism, ed. Herbert Bergman (New York: Peter Lang, 1998), 1:149.

2 As no copies of the Evening Tattler from earlier in August are known to exist, scholars have referred to other papers that quote the passages with citations of their first appearance. Sidney P. Moss suggests that the paragraphs appeared in the Tattler on August 1, noting "the New York Evening Post commented on the forged letter on 2 August." See his Charles Dickens' Quarrel With America (Troy, NY: Whitston, 1984), 138. 
3 Charles Dickens, The Letters of Charles Dickens, ed. Madeline House, Graham Story, and Kathleen Tillotson (Oxford: Clarendon Press, 1974), 3:258.

4 Dickens, 3:311-312.

5 Paul B. Davis, "Dickens and the American Press," Dickens Studies 4 (1968), 34.

6 Dickens, 3:625n.

7 Moss, 106.

8 Moss, 138.

9 Quoted in Dickens, 3:311n.

10 An examination of The Morning Chronicle confirms there was no second letter. See The Morning Chronicle (London), July to September 1842, British Museum File, British Museum Microfilm Service.

11 Gay Wilson Allen, The Solitary Singer (New York: Macmillan, 1955), 51.

12 Jerome Loving, Walt Whitman: The Song of Himself (Berkeley: University of California Press, 1999), 61-62.

\section{A NOTE ON SWINBURNE AND WHITMAN}

In my 1996 article in the Walt Whitman Quarterly Review, I set out to clarify Algernon Charles Swinburne's attitude towards Walt Whitman and suggested that a homophobia dating, I thought, from the early 1870 s encouraged Swinburne's harshening criticism of Whitman. ${ }^{1}$ A source I overlooked at the time, however, provides a bit more information.

In 1972, Derek Hudson published excerpts from the diaries of Arthur J. Munby. ${ }^{2}$ Munby was an English barrister and minor poet who moved through the literary and aesthetic life of Victorian London and who wrote down his daily interactions with the great as well as the obscure (especially the women laborers with whom he was obsessed). He recorded several comments by Swinburne that further document, if only briefly, Swinburne's early enthusiasm for Whitman and that suggest Swinburne's homophobia existed at least as early as the late 1860 s. $^{3}$

On December 2, 1866, Munby wrote in his diary that he had gone to the Arts Club, where he met Swinburne, who spoke of Whitman and who made a comparison of some sort between his own Poems and Ballads (1866) and Whitman, probably in terms of both writers' critical reception:

Going upstairs afterwards I found Swinburne, \& had some talk with him about Poe's Raven, Walt Whitman (whom of course he frantically praised) and Bourdelaire [sic], a certain ribald French poet, whom he declared to be ' 15 million times' better than Tennyson. He spoke of 'my unfortunate book' and its resemblance to Walt Whitman. (233)

A year later, on December 2, 1867, Munby dined with Swinburne again, and the question of homosexuality came up, with Swinburne condemning the practice: 